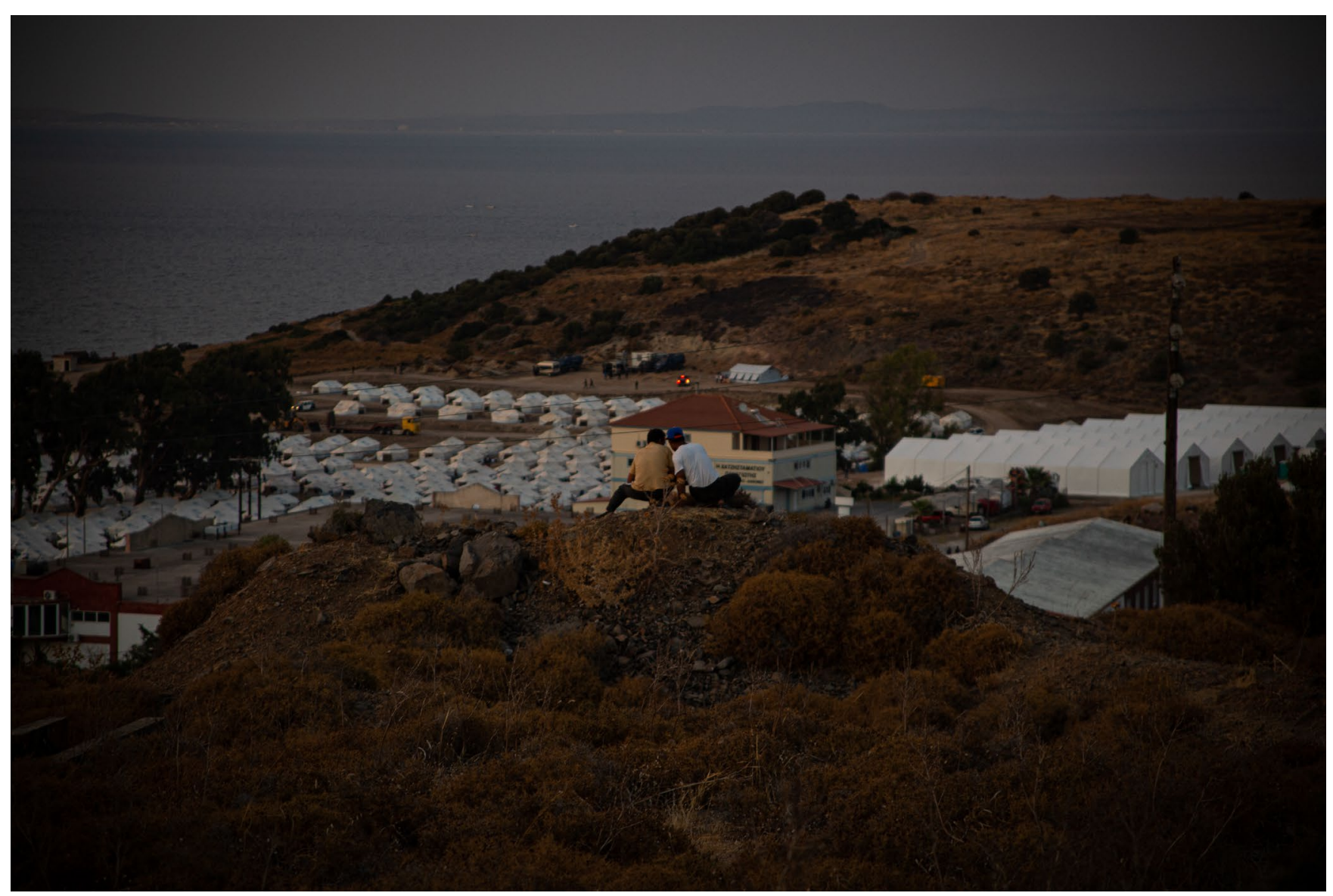

Two men sit on a hill looking down at construction of the new Moria 2.0 (Mavrovouni) camp on the island of Lesvos, Greece in September 2020. Photo: Yousif Al Shewaili/Oxfam.

\title{
TIPPING THE SCALES
}

The role of responsibility- and solidarity-sharing in the situation on the Greek islands

This report assesses the impact of EU countries' refusal to relocate asylum seekers on the Greek islands. It illustrates that they have consistently failed to show solidarity by not delivering on commitments to relocate people, either by refusing to participate in the first place or by not fulfilling their pledges. This has left thousands of people in need of assistance on the Greek islands. EU countries have also consistently tried to avoid their legal obligations by putting barriers in place to keep families apart.

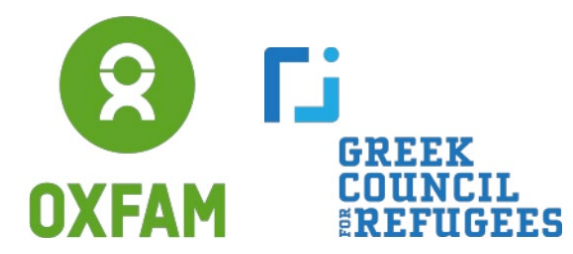




\section{INTRODUCTION}

Since the EU-Turkey Statement in March 2016, ${ }^{1}$ the EU and its member states have invested considerable political capital and financial resources in managing the arrival of asylum seekers from Turkey to Greece. One of the key tenets of the European approach, as already established by the 2015 EU Agenda on Migration, ${ }^{2}$ was setting up large Reception and Identification Centers (RICs, known as 'hotspots') on the Aegean islands, where asylum seekers would be identified, registered and fingerprinted. Each asylum seeker would then be 'channelled into an asylum procedure'; those not in need of international protection would instead be 'channelled to return procedures'. To address the expected pressure on Greek facilities and services, the system also envisioned mechanisms for the EU-wide relocation of people in 'clear need of international protection'. $^{3}$

Unfortunately, conditions on the ground for the past five years paint a different picture. Though the main components of this EU policy (i.e. 'hotspots' and the geographical restriction of newcomers on the islands) gradually became operational throughout 2016 , the envisioned relocation scheme, despite being mandatory, failed to bring sufficient results. ${ }^{4}$ In the meantime, a lack of responsibility-sharing hindered the possibility of improving conditions in the island camps, which remained below standard. This was primarily because more people were pushed into facilities that, by their nature (i.e. 'first-line'/initial reception), were unsuitable for their long-term accommodation, and also too small to host them. In parallel, member states have avoided, through procedural obstacles, taking charge of their responsibilities under binding processes in EU law. The Greek authorities and legislature have tried, at times under EU pressure ${ }^{5}$ to deal with backlogs and overcrowding by changing laws and procedures to send more applicants through expedited processes at the borders, curtailing their rights and bypassing safeguards. ${ }^{6}$

The lack of EU responsibility-sharing also means that Greece has become responsible for an increasing number of people who have been granted international protection. In the first nine months of 2020 alone, more than 27,000 asylum seekers received protected status after a first examination of their application (i.e. 'first instance' decisions), bringing the total number of positive first instance decisions since 2016 to $73,275 .{ }^{7}$ Close to $42 \%$ were women $(30,725$ positive first instance decisions). An additional 10,277 applicants, more than 2,300 of whom women, received protection on appeal between 2016 and the end of $2020 .^{8}$ 
Figure 1: First-instance positive decisions (2016-2020)

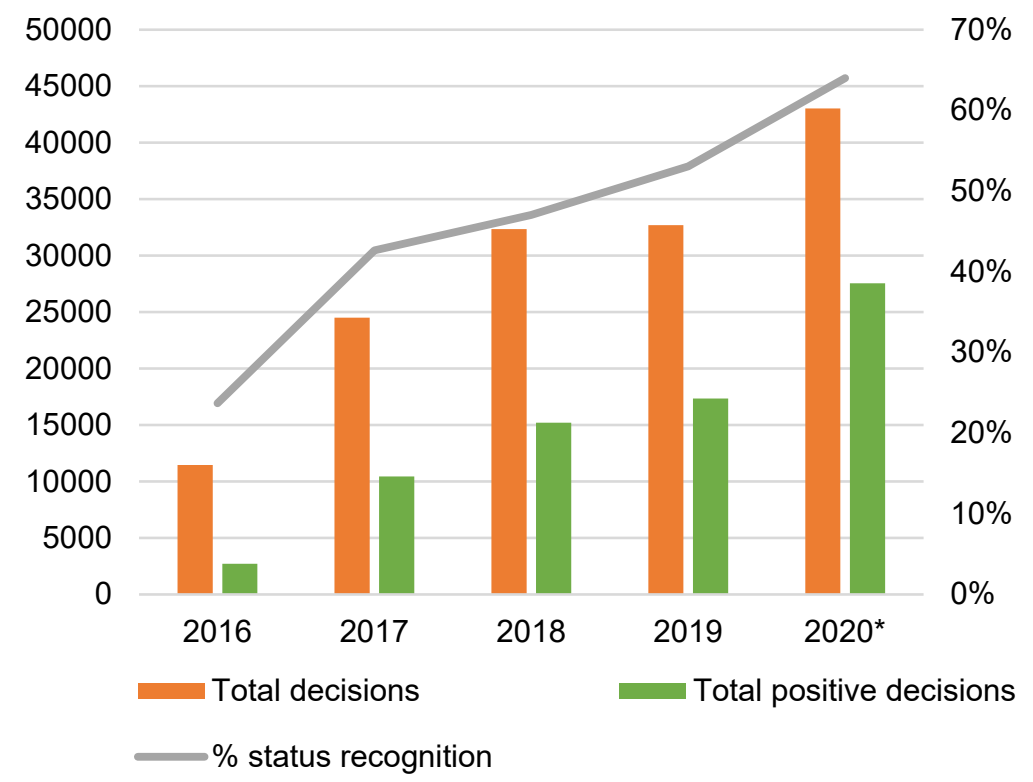

Source: Eurostat Asylum and Managed Migration Database.

https://ec.europa.eu/eurostat/web/asylum-and-managed-migration/data/database

${ }^{*}$ Available up to September

Trapped in Greece by a bureaucratic maze, these recognized refugees often fall between the cracks when it comes to their meaningful inclusion in the host society. Though part of the issue is undeniably related to Greece's financial challenges, the Greek state has also missed every opportunity to work on a comprehensive strategy to support refugees' integration. Furthermore, in March 2020, the Greek government decided to severely limit the time recipients of international protection are allowed to benefit from material support (e.g. accommodation) after their status has been recognized. ${ }^{9}$ Justifying its decision with the need to vacate facilities and the overcrowded island 'hotspots', ${ }^{10}$ the Greek government has increased refugees' risk of homelessness and destitution.

This report looks into some of these challenges. It also assesses the extent to which some components of the New Pact on Asylum and Migration, ${ }^{11}$ launched by the European Commission in September 2020, may impact the situation. The Pact aims to reform the balance between the responsibilities of each member state and European-wide solidarity. However, key similarities to the current state of affairs raise the question of whether the new proposals can have a tangible impact on the situation of asylum seekers at the EU's external borders. 


\section{THE UNFAIR SYSTEM KEEPING FAMILIES APART}

The Common European Asylum System (CEAS) is the EU legislation setting common procedures and standards across member states. People seeking international protection in the EU are obliged to apply for asylum in a single member state, which then becomes responsible for examining their application, under what is known as the 'Dublin III' Regulation. ${ }^{12}$ As a general rule, under Dublin III the applications of persons who have entered the EU irregularly should be examined by the country of first entry, which in practice means by countries at the EU's external borders, such as Greece.

One of the very few exceptions to the rule is an applicant with a family member who has applied for, or been granted, international protection in another member state. In those cases, the applicant should be transferred to the member state in which their family lives. This includes applications by unaccompanied minors, whose best interest is an additional and instrumental principle in the process of determining the responsible member state. When the child has a family member or relative who lives in another EU member state, the child should be reunited with their family unless it is determined that, in exceptional circumstances, this is not in their best interest.

The right of asylum seekers to a family life, which is also guaranteed under Article 8 of the European Convention on Human Rights (ECHR), is an overarching criterion and should guide every step of the procedure. ${ }^{13}$ However, in practice, member states prioritize the first entry clause instead. ${ }^{14}$

\section{FLAWS IN THE DUBLIN SYSTEM}

Naturally, the current responsibility-sharing system results in most asylum applications being submitted in countries with an external EU border, such as Greece, and to a lesser extent, Italy. However, when the number of applications increases, the flaws of the Dublin system become evident. The most striking example of this came in 2015, when more than 850,000 people reached Greece by sea. ${ }^{15}$ The decision to keep the borders open, which among other consequences led to the de facto suspension of the Dublin Regulation ('first entry' clause), is perhaps the only reason a humanitarian tragedy of far greater proportions was averted. Yet even in 2019, amid significantly diminished sea arrivals (less than $7 \%$ compared to 2015 ), the 'hotspot' system reached a breaking point, with more than 38,000 people having to reside in facilities with a nominal capacity of less than 13,400 by the end of the year. ${ }^{16}$ 
The flaws in the Dublin system have been recognized for a long time. ${ }^{17}$ In 2011, the European Court of Human Rights, in the judgment of MSS v.

Belgium \& Greece (application No. 30696/09), helped illustrate how the presumption of uniform reception/asylum systems throughout the EU and horizontal compliance with the EU asylum acquis, upon which the Dublin system is based, was flawed. The Court ruled that upon his return to Greece the applicant lacked effective access to asylum, reception and determination procedures and had been exposed to appalling conditions in detention, which inter alia violated Article 3 (prohibition of inhuman or degrading treatment or punishment) of the ECHR. ${ }^{18}$ In failing to take into consideration the prevalent situation in Greece before sending the applicant back, the Court also ruled that Belgium had similarly violated Article 3 of the ECHR. It also noted the pressure on frontline member states due to the Dublin system, and how 'the situation [was] exacerbated' by the return of asylum seekers under the same system. ${ }^{19}$ The judgement had an instrumental role in the suspension of returns to Greece under the Dublin Regulation until December 2016, when the Commission recommended their gradual resumption, despite the 'tremendous pressure' under which the Greek asylum and reception systems still remained. ${ }^{20}$

Up to that point, most member states had refrained from sending significant numbers of 'take back' requests to Greece, with the sole exception of Hungary, which even in 2016 had asked Greece to take back 5,683 asylum seekers under the Dublin Regulation. Following the Commission's recommendation, others re-started sending 'take back' requests to Greece as well. Regardless of the recognition of the flawed aspects of the system between 2017 and February 2020, Greece was asked to take back 26,187 asylum seekers to assess their applications. This figure is higher even than the number of 'take charge' requests sent by Greece to other member states on family reunification ${ }^{21}$ grounds $(21,225)$ in the same period. Although actual transfers have been minimal (a total of 58), the large number of requests, despite the wellknown conditions in Greece, are indicative of EU countries' prioritization of the first entry clause rather than humanitarian clauses, which would have served as an indication of their solidarity.

\section{Failure of member states to share responsibility}

Two European Council decisions in September 2015 aimed at assisting Greece and Italy at the height of the European refugee crisis. ${ }^{22}$ Member states agreed to take responsibility for a total of 160,000 eligible asylum seekers, ultimately pledging to relocate a total of $63,302^{23}$ people arriving in Greece between September 2015 and September 2017. ${ }^{24}$

However, only a third of that number $(21,999)$ was actually relocated 25 just $22 \%$ of the total number of asylum seekers reaching Greece in the period. Worse, the scheme exposed deep political divisions between EU member states, with the strong refusal of Poland and Hungary to accept any mandatory relocation quotas, and the UK and Denmark opting out. ${ }^{26}$ This political schism not only slowed relocations, it also prevented any 
agreement on mandatory relocation mechanisms as part of European Common Asylum System reforms. Meanwhile, even 'willing' member states only agreed to relocate asylum seekers that had arrived in Greece up to March 2016, ${ }^{27}$ de facto limiting the number of people who could have been relocated.

As no agreement on an EU-wide responsibility-sharing mechanism has since been achieved, some member states have offered to participate in ad hoc initiatives to relocate asylum seekers out of Greece. In 2020, a number of 'willing' member states ${ }^{28}$ pledged to relocate 1,600 unaccompanied children. After the fire that devastated Moria refugee camp on Lesbos in September 2020, the voluntary relocation scheme was broadened to also include children with medical conditions and their families, as well as beneficiaries of international protection, bringing the total relocation pledges to $5,100 .{ }^{29}$ However, by the end of 2020 , only 2,050 people had been relocated to 10 member states. ${ }^{30}$ This is partly due to flight restrictions related to COVID-19, and partly due to cumbersome procedures, slow implementation and 'cherry picking' practices on behalf of at least some member states, who have failed to consider the realities on the ground in Greece.

\section{FAMILY REUNIFICATION AND 'TAKE CHARGE' REQUESTS}

\section{Family reunification system}

One group of asylum seekers with a chance of escaping the difficult conditions in Greece are people with family members in other EU countries. The family reunification mechanism has been designed to support applicants' right to family unity, and to improve responsibilitysharing among member states. However, from the outset, it has included elements that hinder the possibility of achieving its objectives. The regulation leaves significant room for interpretation on core elements of procedure, such as what constitutes the best interests of a child, while a priori excluding persons with close family ties from the possibility of reuniting with their families.

For example, the family definition within Dublin III is restrictive, only taking into account nuclear family connections (i.e. spouses, parents and children under 18) that existed in their country of origin. ${ }^{31}$ In the case of unaccompanied minors, close relatives (e.g. uncle, grandmother) are also eligible, provided reunification with them is in the best interests of the child. This immediately excludes a broader set of close family ties between asylum seekers, including between adult siblings, parents and their adult children, and those created after escaping war and persecution - for example, a couple who married after fleeing home. ${ }^{32}$

Family reunifications are also made more difficult by the practices of member states, many of which do not consistently provide adequate and coherent information to applicants in a language they can understand. As 
a result, asylum seekers not represented by a lawyer struggle to understand the procedure, and their related rights and obligations. ${ }^{33}$ They find it difficult to communicate with authorities when asked to provide documents that prove existing ties with family members in other European countries. As state-funded free legal aid is not provided in Greece, asylum seekers must rely on legal support from NGOs, ${ }^{34}$ which are objectively unable to cover the gap left by the state.

\section{Box 1: Questionable grounds for rejection of family members}

In some cases, member states reject 'take charge' requests on the grounds that the relative residing in their territory had not previously mentioned the existence of family members in another country - even if they had not been asked about this topic at any point during their own asylum interviews. ${ }^{35}$

\section{'Take charge' requests}

Although the Regulation is supposed to provide a quick and straightforward way to determine each member state's responsibility, the reality is extensive backlogs, long delays and protracted periods of waiting:

- The process begins with a 'take charge' request from the first member state within three months of the application being lodged. ${ }^{36}$

- Then the second member state replies after determining whether it is responsible for the application within two months of receiving the request. ${ }^{37}$

- Finally, the actual transfer should take place within six months of acceptance of the 'take charge' request (this can be extended by up to an additional 12 months). ${ }^{38}$

Failure to comply with any of the deadlines has direct consequences for applicants' prospects of family reunification, as it leads to the immediate transfer of the responsibility to the 'non-compliant' state. This fails to take into account realities on the ground, or of a transfer, ${ }^{39}$ which are exacerbated by member states' evasive practices.

In 2019, Greece sent out 5,459 'take charge' requests to other member states. Of these, $3,275(59.9 \%)$ were based on family reunification provisions, and 1,496 on humanitarian grounds. ${ }^{40}$ Only $1,819(55.5 \%)$ of the family reunification requests were eventually accepted by other member states, along with $488(32.7 \%)$ of the humanitarian requests. ${ }^{41}$

In 2020, Greece addressed 2,977 'take charge' requests to other member states, ${ }^{42}$ and received 7,403 requests $(1,323$ of whom concerned single women or single women with young children) from other member states, ${ }^{43}$ a number disproportionally higher. Furthermore, in 2020 , out of a total of 6,512 replies Greece received, ${ }^{44} 2,030(31 \%)$ cases ('take charge' requests) were accepted by receiving member states, ${ }^{45}$ while $4,482(69 \%)$ cases were rejected. 


\section{REJECTIONS}

One of the primary reasons for a member state to reject a case is failure to meet the three-month deadline for the 'take charge' request from Greece. In most cases, this is not the asylum seeker's fault, but is due to inadequate reception conditions, insufficient information on rights, lack of legal aid and incorrect age registration of minors, etc.

Yet, the onus is on applicants to provide ${ }^{46}$ formal documents proving family ties with those in the receiving state, along with written consent from their relative and proof of the latter's legal status within three months. As is often the case when people have had to flee their country or have been on the move for a long period of time, personal documents, such as marriage or birth certificates, may have gone missing. Further, governments in countries of origin may pose obstacles to issuing new ones.

In the absence of original personal documents, member states often require expensive and time-consuming alternatives for proving family links. Spain, for example, in the absence of proper documentation, regularly asks applicants for a DNA test, ${ }^{47}$ which costs approximately $€ 500$ per person. Applicants in Greece can ask for support from NGOs (which often do not have the means and/or the capacity to help on this matter) or the public forensic service, which is available only in large Greek cities, ${ }^{48}$ in order to take the test for free. This means having to wait for a long time for an appointment, which in turn means risking missing their deadline. During 2020, a DNA test was used in more than 100 cases of family reunification to prove family links. ${ }^{49}$ Documents nearly always need to be translated at the applicants' expense, although most member states accept translations into English. ${ }^{50,51}$

Without legal assistance it is nearly impossible for asylum seekers to meet these obligations, let alone within the deadlines. As state-funded legal aid is not provided for first instance procedures, applicants must rely on the limited legal support provided by NGOs. In addition, the severe lack of guardians, ${ }^{52}$ especially on the Greek islands, results in children not having representation and/or support for lodging their family reunification applications. 
Box 2: Questionable grounds for rejecting 'take charge' requests for children

With child applicants, some member states reject family reunification cases based on a questionable interpretation of the 'best interest of the child'. ${ }^{53}$ They also reject cases in which they do not consider the child to be 'unaccompanied' - for instance, when a more distant family member or relative is already present in Greece. In doing so, government officials prevent the child from reuniting with a closer family member, such as a sibling. Sometimes cases are rejected on a technicality, such as when member states do not consider the best interest assessment form to be valid because it was completed by a professional not officially appointed by the unaccompanied minor or the Public Prosecutor for Minors.

Another set of problems in family reunification is related to age assessments of unaccompanied children. Increasingly, member states ${ }^{54}$ reject cases because the age assessments have not been conducted according to the receiving country's methods. ${ }^{55}$ Often, member states rely on physical assessments (e.g. x-rays) as a definitive indicator of age, even though medical NGOs have highlighted these as more intrusive and prone to a large margin of error. ${ }^{56}$

Member states have an obligation under the Dublin Regulation to provide adequate and coherent information to applicants in a language that they understand. ${ }^{57}$ However, this is not always fulfilled: a lack of answers and timely information have been among the biggest challenges faced by asylum seekers when applying for family reunification. ${ }^{58}$

Member states' rejection letters usually provide insufficient or no reasoning, and most of the time, the rejection is based on the formal rules rather than the substantial rules and binding criteria laid down in the Regulation (such as family unity and the best interests of the child). This means that a number of rejections have been based on missing documentation, bearing no explanation for why the lack of a particular document prevents acceptance of the case. ${ }^{59}$

\section{Member states making deadlines even harder}

Following a 2017 ruling by the Court of Justice of the European Union (CJEU), ${ }^{60}$ many member states - most notably Germany ${ }^{61}$ - have changed the way in which they calculate the start of the three-month countdown for 'take charge' requests. Instead of starting when an asylum application is lodged (i.e. fully registered) in Greece, they have begun to calculate the countdown from when a person first expresses their will to seek international protection (i.e. initial registration and fingerprinting) ${ }^{62}$

This reflects a blatant disregard for the broader challenges faced by asylum seekers and the Greek administration, especially in times of crisis (e.g. due to large numbers of arrivals or the COVID-19 pandemic); the significant delays between initial and full registration; and the lack of legal aid and guardians for unaccompanied children.

Challenges begin with the timely identification of family reunification cases among newly arrived asylum seekers in Greece by civil society
'We never got a case accepted on the first try. Never.'

- Ani Chiban, Deputy Director of Fenix - Humanitarian Legal Aid 
organizations. After identifying these cases, NGOs provide information and support to applicants with the collection of necessary documents. It is also up to NGOs to notify the Greek Asylum Service (GAS) of these cases, so they can prioritize - at the expense of other asylum seekers waiting for their turn - their official registration before the three months expire. ${ }^{63}$

\section{Box 3: The impact of COVID-19}

At the onset of the pandemic, nearly all EU countries temporarily suspended Dublin transfers. ${ }^{64}$ Meanwhile, those people entitled to family reunification were at first excluded from any other form of relocation, including the ad hoc arrangements agreed between member states during 2020.

During the pandemic, it has been particularly difficult for applicants to meet deadlines or provide the necessary documentation. However, member states have showed no flexibility, and deadlines have not been extended. The GAS was closed to the public, and applicants could not present themselves nor submit their documents unless they had a lawyer who would deal with their case via email. Getting access to documents was also very difficult, as embassies were closed, as were offices in asylum seekers' countries of origin, even while the Dublin Unit continued to work.

The pandemic disrupted the scheduling of transfers from Greece to other member states throughout 2020. Delays were also reported; before the pandemic, the average time for a transfer was three to four months after receiving a positive decision from the other member state. However, during 2020, due to a number of COVID-19-related constraints, ${ }^{65}$ transfers, when available, took place right before the six-month window (from the positive decision) was due to expire. 


\section{THE IMPACTS OF A FAILING SYSTEM}

Figure 2: Arrivals and first-time asylum applications in Greece between 2016-2020

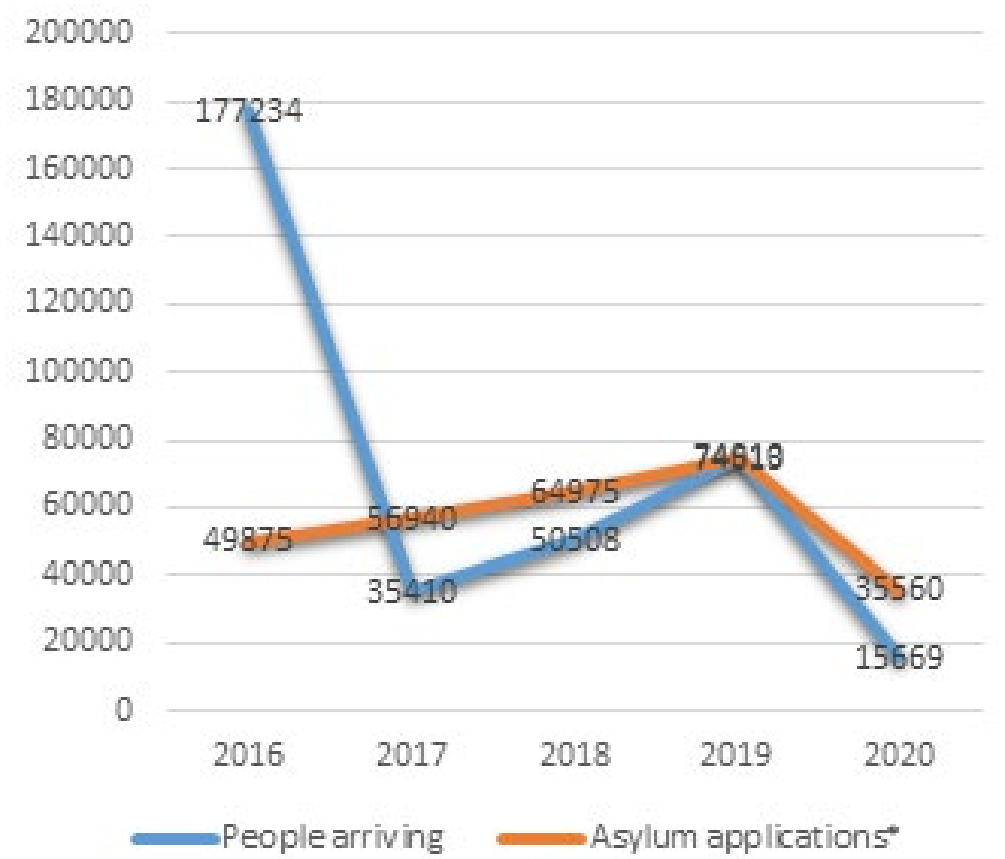

Sources: UNHCR Operational Portal, Refugee Situations, Mediterranean Situation - Greece. Sea and land arrivals monthly. https://data2.unhcr.org/en/situations/mediterranean/location/5179; and Eurostat Asylum and Managed Migration Database. https://ec.europa.eu/eurostat/web/asylum-andmanaged-migration/data/database.

*2020 data on first-time asylum applications only available up to November.

The closure of the 'Balkan route' 66 and the subsequent enforcement of the EU-Turkey Statement in March 2016 reaffirmed the imbalances in the Dublin system's allocation of responsibility.

Between 2016-2020, more than 350,000 people reached Greece by sea $(86 \%)$ and land $(14 \%)$ in search of safety and a better life. ${ }^{67}$ As most remained trapped in Greece after March 2016, by November 2020, $289,560(81.7 \%)$ had applied for asylum in the country. ${ }^{68}$ Application numbers remained high even in $2020(34,220)$, despite the overall decrease in arrivals since the COVID-19 pandemic hit Greece, which seems to have coincided with an increase in numbers of alleged pushbacks at Greece's land and sea borders that are cause for concern to this day. ${ }^{69}$

With other member states refusing to take charge of a significant proportion of these applications, in 2018 and 2019 Greece was responsible for examining slightly more than $10 \%$ of all first-time asylum applications submitted in the EU, and slightly more than $9 \%$ in $2020 .{ }^{70}$ Even without considering factors such as GDP and the size of 
population, this clearly puts disproportionate pressure on the Greek asylum system. In turn, this disproportionate pressure is among the main reasons for procedural delays and protracted uncertainty for asylum seekers, who are in most cases forced to reside in unsuitable and overcrowded camps.

\section{LONG DELAYS AND PERSISTENT BACKLOGS}

Figure 3: Applications for international protection in 2019 relative to population size (2019), country size (2015) and GDP (2018)

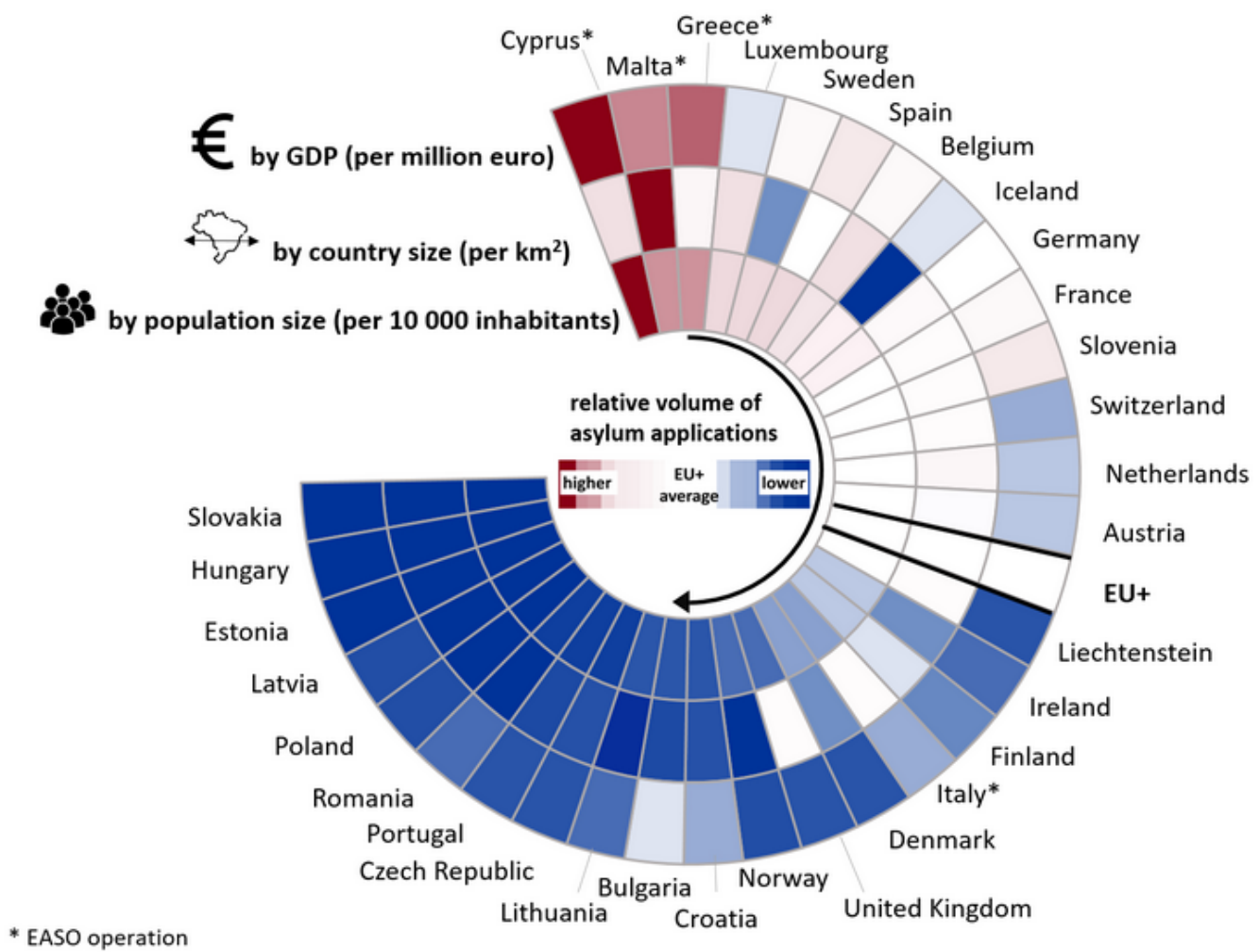

Notes: Countries are sorted by the number of applications relative to population size (from higher to lower volumes, indicated by the arrow). The shades indicate the number of relative applications received compared to the EU+ baseline.

Source: EASO Asylum Report 2020. Section 4.8: 'Socio-economic indicators to analyse trends in asylum in Europe'. https://easo.europa.eu/asylum-report-2020

Throughout 2019, asylum seekers residing in camps in mainland Greece frequently had to wait between four and six months to be fully registered, with years passing before their first asylum interview was conducted. In some cases, interviews were scheduled for as far out as $2024 .{ }^{71}$ In the Aegean islands, where asylum procedures are subject to the $2016 \mathrm{EU}$ Turkey Statement and therefore often expedited, ${ }^{72}$ the average duration of the fast-track border procedure was still over seven months by the end of $2019 .{ }^{73}$ By November 2020, more than 65,000 asylum applications were still pending at first instance in Greece. ${ }^{74}$ 
While the number of pending asylum applications in Greece dropped throughout 2020, this is likely in large part due to the pandemic, and most notably the two-month suspension of personal interviews between 13 March and 15 May. ${ }^{75}$ At the beginning of March, the Greek government also curtailed the ability of newly arrived refugees to register and submit asylum applications ${ }^{76}$ which statistics suggest freed up capacity to reduce backlogs at the expense of the rights of newcomers. ${ }^{77}$ Even so, at the end of the year, the number of pending applications remained nearly twice as high as the decisions issued in the first three quarters of $2020 .{ }^{78}$

In relative numbers, the backlog in Greece is one of the largest in the Europe. Greece's backlog is the fourth largest in the EU, after Germany, France and Spain, followed by Italy - four countries which collectively represents close to $60 \%$ of the EU's population and more than $60 \%$ of its GDP in $2019 .{ }^{79}$ By contrast, Greece's proportions of EU population and GDP were $2.4 \%$ and $1.3 \%$, respectively - closer to Belgium, the Czech Republic, Finland, Hungary, Portugal, Romania and Sweden, which are dealing with far fewer cases (See Annex I for a full table).

\section{Figure 4: First-time applications and pending cases as of October 2020}

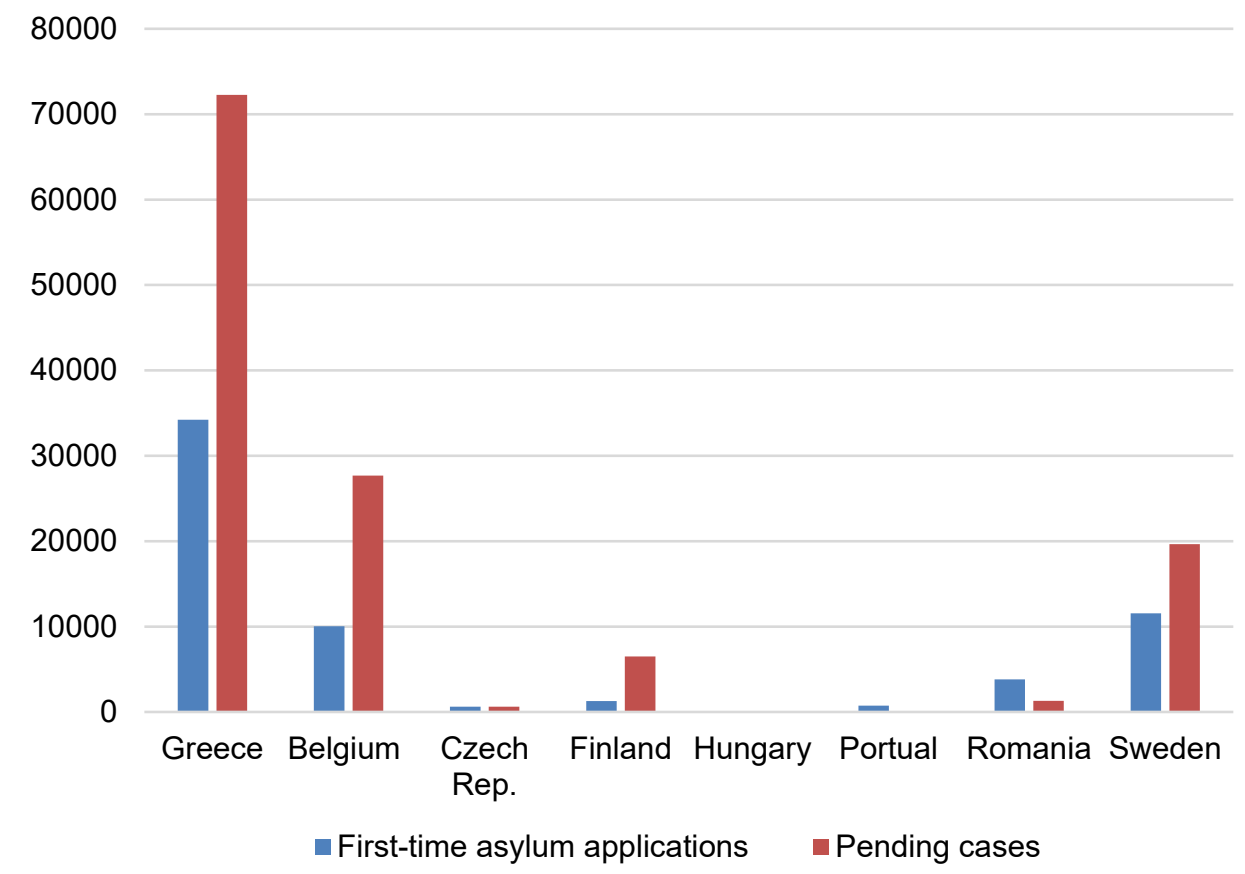

Source: Eurostat Asylum and Managed Migration Database.

https://ec.europa.eu/eurostat/web/asylum-and-managed-migration/data/database 


\section{UNACCEPTABLE CONDITIONS IN CAMPS}

The consequences of the lack of responsibility-sharing are most vividly encapsulated in the substandard and at times inhumane conditions under which asylum seekers have been forced to live. Both island and, to a lesser extent, mainland camps have been repeatedly criticized for failing to respect the safety and dignity of their residents and not complying with EU legal standards. ${ }^{80}$

By the end of 2019 , more than 38,000 asylum seekers were being forced to live in severely challenging conditions in the 'hotspot' island camps, which at the time had a nominal capacity of 6,178 places. ${ }^{81}$ Yet even in 2020 , amid a large reduction in sea arrivals $(9,687$ by the end of 2020 , as opposed to 59,726 by end of 2019) ${ }^{82}$ and a welcome increase in transfers to the mainland (33,617 in 2020 as opposed to 21,504 in 2019), ${ }^{83}$ conditions remained dire. By year's end, 17,005 asylum seekers and refugees remained on the Eastern Aegean islands, the majority of whom $(14,265)$ were still living in hotspot camps. ${ }^{84}$ Nearly half $(48 \%)$ were women $(21 \%)$ and children $(27 \%) .{ }^{85}$ More than 7,000 of these, over $30 \%$ of whom were children, were forced to live in unsuitable conditions in the temporary Mavrovouni camp in Lesbos (Moria 2.0). The camp flooded once more in December, leaving many struggling with the mud just days before Christmas. ${ }^{86}$ Recently, the Greek Ministry of Migration and Asylum confirmed lead concentrations above acceptable levels in a section of the camp, leading to further concerns being raised by civil society organizations. ${ }^{87}$ The 'hotspots' of Chios and Samos - where asylum seekers are frequently bitten by snakes, scorpions and rats ${ }^{88}$ are also severely strained, operating well beyond their capacity at $236 \%$ and $531 \%$, respectively, at the end of 2020 .

The conditions take a significant toll on the mental health of applicants. International Rescue Committee research has found that one in three asylum seekers report suicidal thoughts, and one in five have already attempted to take their lives due to the impact of prolonged containment in 2018-20.89

The situation on the mainland does not significantly differ. By the end of 2020 , more than 28,000 children (43\%), women (24\%) and men (33\%) were living in the country's 32 mainland sites, the majority of which remained near the limits of or well beyond their capacity (i.e. between $100 \%$ and $127 \%$ in 10 cases). Among their residents, close to 3,000 continued to reside in tents and rub halls (i.e. large tents) while close to 750 were living in makeshift shelters. Despite the significant proportion of child residents, with scarce exceptions, they all still lacked access to formal education, while only 18 had child-friendly spaces. Similarly, only 18 out of the 32 sites had female-friendly spaces, even though women constitute more than a fifth of each site's population in the majority of cases. ${ }^{90}$
'Particularly us, single women, [we feel] fear. At night it is dark and we cannot go to the toilet. We feel abandoned.'

$-\mathrm{R}$, single woman asylum seeker on Lesvos

'The lack of electricity is a very big problem. Even during the few hours, during which we were told we would have electricity, this doesn't happen. During the day, it is not difficult, but at night, if there is not light, it is not safe. Tents are [also] too small and too many people reside in them. There are also many pregnant women and families with small children in the camp. Conditions are particularly difficult for them as they are not suitable for vulnerable populations. It is dirty and pregnant women and children may easily get sick.'

- $R$, single woman asylum seeker on Lesvos 


\section{IMPACTS ON THE PEOPLE OF THE AEGEAN ISLANDS}

With no end in sight to a five-year-long humanitarian tragedy, the lack of European responsibility-sharing has impacted the lives of host communities on the Greek islands. They have witnessed their localities transformed from spaces of exemplary solidarity to overcrowded open-air prisons for thousands of asylum seekers who have become victims of the EU's externalization agenda. Much like Greece vis-à-vis the EU, so too the 'hotspot' islands vis-à-vis the rest of the country have become virtually segregated from other parts of Greece on account of the EUTurkey Statement and its impact on the EU 'hotspot' approach in Greece. Increasingly trapped in an impasse not of their own making, the local communities have 'experienced the degradation of their life and the general marginalization of their locality as an injustice directed towards themselves'. ${ }^{91}$

It has also opened up space for less tolerant stances to gain legitimization, with growing instances of intolerance and xenophobia over the years. ${ }^{92}$ This further deepens the challenges for the inclusion of those who are ultimately recognized as beneficiaries of international protection in Greece.

\section{LACK OF STRATEGIC PLANNING TO SUPPORT RECOGNIZED REFUGEES}

The lack of responsibility-sharing has an impact not only on Greece's asylum procedures, but also on its ability to support recognized refugees. In 2018-20, the number of people in Greece recognized as entitled to international protection went up from 15,805 in 2018 to 35,372 in $2020 .{ }^{93}$ This has further overstretched the capacity of the Greek government, which also lacks a comprehensive integration strategy to address the inevitable outcome of the disproportionate responsibility shouldered by frontline member states (in this case, Greece), in the context of the CEAS.

On the Aegean islands, access to crucial rights such as (formal) education has been severely limited in the past few years due to the lack of infrastructure (e.g. school places) to be expected in small communities. This has been exacerbated by the supposed temporary nature of RCls/'hotspots'. ${ }^{94}$ As a result, many refugees have been recognized without ever having benefited from integration/necessary support. This means that they have extremely limited opportunities to integrate into society or make a living, not least as they still have to overcome the language barrier. Bureaucratic obstacles and delays, such as acquiring residence permits (up to a year in GCR's experience), fiscal registration and social security numbers, further hinder their access to 
socioeconomic life, such as finding a job or accessing public

healthcare. ${ }^{95}$ These delays and obstacles also challenge refugees' ability to access accommodation support (rent subsidies) under the only largescale integration programme currently available in Greece (Helios). ${ }^{96}$ Greece's financial situation leaves little room for optimism either. As of the third quarter of 2020, Greece had the highest government debt-toGDP ratio in the EU $(199.9 \%)^{97}$ and the second-highest unemployment rate $(16.1 \%) .{ }^{98}$

On top of this, as of 1 June 2020, beneficiaries of international protection in Greece are required to leave their EU-funded accommodation within a month of receiving their positive decision. This decision means they lose all material assistance they were entitled to during the asylum procedure, rather than enjoying a 'grace period' of six months, as was the case before June, which allowed them time to find their footing in Greek society. ${ }^{99}$ The exceptions to this rule are:

- families with at least one member suffering from a health condition of such severity that their life would be in danger if support were removed (up to two additional months);

- women (and their families) during advanced or dangerous pregnancies, or in the post-natal phase (two additional months from the time of giving birth); and

- unaccompanied minors who, upon reaching 18 , cannot be immediately evicted from their accommodation on grounds of vulnerability or abruptly interrupting their education. They can be referred to apartment-based accommodation for up to three months from the time they are placed in such accommodation.

However, even in such cases, the extra support provided is severely limited in its duration, after which all provisions are automatically terminated. ${ }^{100}$

Among other reasons, this decision was justified by the Greek minister of migration and asylum as a means to make Greece a 'less attractive destination for migration flows', ${ }^{101}$ while contributing to the islands' 'decongestion'. ${ }^{102}$ The impact of these changes was highlighted in the summer months of 2020 , when refugees who were finally allowed to leave the islands after having their status recognized were left homeless on the streets of Athens. ${ }^{103}$ Since then, as pointed out by civil society organizations in December 2020, more than 11,000 people have been further informed they need to leave their accommodation, ${ }^{104}$ amid an ongoing nationwide pandemic-related lockdown. The lockdown makes it nearly impossible for many to search for accommodation, even if they have the resources to do so in the first place. This further exacerbates the risk of homelessness and destitution for people who, having managed to flee war and persecution, are increasingly exposed to the risk of violence and exploitation within the EU's borders. ${ }^{105}$ 


\section{THE ASYLUM AND MIGRATION PACT: A NEW PROPOSAL}

In September 2020, the European Commission presented a proposal: the new 'Pact on Migration and Asylum', with a promise that it would avoid the failings of the past. The Pact includes legislative proposals and policy blueprints, asserting that 'all member states should contribute to solidarity on a constant basis', ${ }^{106}$ but the extent to which this promise can be kept in practice remains unclear.

\section{DETERMINING THE MEMBER STATE RESPONSIBLE}

Under the proposal, the Dublin III Regulation would be replaced by a new Asylum and Migration Management Regulation. However, the mechanism for determining the responsibility of member states will remain largely the same and has already been critiqued for its focus on limiting secondary movement. ${ }^{107}$ According to the new proposal, the first member state of entry will remain the one responsible for processing asylum applications, unless the applicant meets certain criteria, such as being able to prove they have a family member legally residing in another country, a family member applying for international protection in another EU country, or having residency in or a visa for another country.

The new regulation makes two positive steps:

- It introduces a new criterion for the responsibility of a member state from which the applicant is in possession of an educational diploma; and

- It expands the definition of 'family' to allow siblings to reunite, and to recognize family ties that were created after leaving countries of origin but before arriving in the EU.

While this is positive, it is noteworthy that the European Parliament's 2017 proposal for reforming Dublin III gave greater consideration to applicants' ties and preferences. ${ }^{108}$ It was abandoned when the Council could not reach an agreement on the same proposal.

According to the Commission's proposal, asylum seekers will be required to remain in the country responsible for examining their application and may be denied access to reception conditions in any other member state. This measure is meant to prohibit unauthorized movements that have not been coordinated by states. As for authorized transfers, the Commission is proposing to reduce the relevant time frames: 'take charge' requests must be sent within two months from the date on which an asylum 
seeker's application was registered. The transfer to the country responsible for their case must then take place within six months of the acceptance of the 'take charge' request. Shortening these timelines are likely to create significant problems for asylum seekers and to the administrative units in member states responsible for transfer (the 'Dublin Units'). The proposal to reduce timelines also runs counter to some of the outcomes of an earlier evaluation of the Dublin Regulation that was prepared for the Commission in 2015, which highlighted that shortening procedures was unrealistic. ${ }^{109}$

\section{RESPONSIBILITY-SHARING MECHANISMS}

The Commission also proposes expanding the responsibility-sharing mechanisms. According to the proposal, responsibility-sharing would become mandatory across the EU but, in regular times, would only apply to 'search and rescue operations that generate recurring arrivals of third country nationals or stateless persons onto the territory of a member state and vulnerable persons...' ${ }^{110}$ Each year, the Commission will publish expected required relocations and each member state's quota, half of which would be based on countries' population size and half of which would be based on their GDP. Each member state will be able to fill its quota in one of the following ways:

- Relocation of asylum seekers: Asylum seekers who are not going through accelerated border procedures could be relocated to other member states. Member states would receive $€ 10,000$ per relocation. The decision on whether an application will be examined in a regular or an accelerated procedure would be made at the first stage after the arrival of the asylum seeker in the EU. The Commission proposes that applicants from countries for whom the EU-wide recognition rate of asylum applications is less than $20 \%$ should be assigned to accelerated border procedures. This means that, unless exceptional circumstances apply, these nationalities would not be eligible for relocation.

- Return sponsorship: Instead of relocation, a member state could choose to display solidarity by becoming responsible for coordinating and paying for ('sponsoring') returns of third country nationals from the territory of another member state to their countries of origin. This type of support could include policy dialogues, assisted voluntary returns and reintegration, ensuring delivery of travel documents, etc. If, after eight months, the return did not happen, the 'sponsoring' member state would have to relocate the individual concerned to continue the (return) procedure from its territory.

- Capacity-building measures: Solidarity contributions could consist of measures aimed at strengthening the capacity of a specific member state in asylum, reception or return. Examples of such support could include additional reception capacity, infrastructure, financing migration management in relevant non-EU countries, and supporting returns infrastructure. 
In addition, the Commission also proposes to declare situations of 'migratory pressure' if and when a member state's capacity in the field of asylum and migration falls significantly short of needs. If the Commission finds that a member state is under migratory pressure, other member states will again be asked to adopt solidarity measures in the form of relocations of asylum seekers and refugees who have arrived over the preceding three years, return sponsorships, or specific support measures identified as necessary by the Commission.

\section{LIKELY IMPACT OF THE PROPOSAL}

Given the current distrust and ongoing lack of solidarity between member states, it is hard to see how the proposed mechanism will meet the needs of refugees and asylum seekers trapped in Greece, or Greece's need for tangible support. While the proposed Regulation includes mechanisms aimed at increasing contributions from member states, ${ }^{111}$ their compliance with these mechanisms still depends on political will. It remains to be seen if member states that refused mandatory relocations in the past will agree to them in the future. Others have already concluded that the new proposals are 'unlikely to succeed in resolving political divisions over responsibility-sharing in Europe' and that the flexibility allotted to member states to choose between types of solidarity 'comes at the expense of predictable and tangible support for EU states facing migratory pressure.' 112 The lack of predictability may incentivize member states with external borders to do less in order to themselves avoid a disproportionate responsibility. ${ }^{113}$ This can work to the detriment of the system as a whole, while exposing people seeking international protection to increased risks of being denied their rights, or even refoulement. ${ }^{114}$

An additional complication is likely to have a negative impact on the rights of vulnerable asylum seekers and women, in particular. As mentioned above, the Commission proposes to identify when a member state is facing capacity challenges due to the presence of vulnerable asylum seekers in relocation mechanisms and to include them in solidarity mechanisms. However, five years of experience on the Greek islands have shown that identifying vulnerabilities can be a challenging exercise. The small number of available doctors, interpreters and medical equipment is no match for the level of need in the reception centres . ${ }^{115}$ In the past, NGOs in Greece reported ${ }^{116}$ that in many cases, the wait for medical checks to determine vulnerability was so long that reception and identification procedures had concluded before the individuals concerned could actually undergo a vulnerability assessment.

As a result, attempts to assess the number of vulnerable persons in reception centres are likely to fall short of the actual number, due to low rates of identification. Specifically, people with less visible injuries or conditions - e.g. survivors of sexual and gender-based violence, and victims of torture - will go unnoticed. Rather than receiving the protection 
that should come with relocation, their needs are likely to be ignored. This will have a disproportionate impact on women, who are more vulnerable in migration and whose medical needs are often overlooked by medical staff. The asylum seekers who have not been identified as vulnerable are also at a higher risk of undergoing accelerated procedures with reduced safeguards and, potentially, being returned to countries where they are not safe.

The Pact in its current form fails to strike a satisfying balance between responsibility and solidarity, particularly when conditions in a member state make it evident that it is struggling to comply with its responsibilities. ${ }^{117}$ Without underestimating the positive elements included in the Commission's proposal, experience from Greece illustrates that more needs to be done to ensure that the unequal distribution of responsibilities between member states does not result in undue pressure on asylum seekers. As the European Parliament and the EU member states negotiate their amendments to the Commission proposals, they will need to carefully assess the impact that the proposed mechanism will have on the rights of asylum seekers in Europe. Any agreements should represent not only the interests of the member states themselves, but also of the women, men and children who seek their protection.

\section{CONCLUSIONS AND RECOMMENDATIONS}

The ongoing pressure on the reception system in Greece is a result of structural failures, erroneous implementation and a lack of political will to improve the situation across the EU. Its result is uncertainty and substandard, frequently inhumane living conditions to which asylumseeking men, women and children have been exposed for the past five years. The default allocation of responsibility under the Dublin system has been unfair both to asylum seekers and to member states with external borders.

The Commission's proposed new Pact on Asylum and Migration, will not, in itself, offer a solution that would ensure 'no more Morias', as Commissioner Johansson said at the launch of the Pact. ${ }^{118}$ Reform of the rules will not, in itself, improve their implementation or create political will. Therefore, it is essential for work to continue on parallel tracks: while the Pact is being discussed by EU legislators, implementation of the existing rules must be monitored and improved.

We urge the Government of Greece (with the support of the EU) to:

- Host asylum seekers in facilities that meet basic reception standards and avoid the use of de facto detention. Reception and identification facilities at the borders should only be used for the
'I am very pessimistic about countries accepting broader responsibilities when they don't accept the responsibilities they have now. With the new shorter deadlines that are proposed in the new pact, not only to process the asylum applications but also the Dublin requests, it will become even more difficult for Greece, which is already struggling with the three-month deadline from arrival or registration.'

- Ani Chiban, Deputy Director of Fenix - Humanitarian Legal Aid 
minimum time necessary to ensure proper identification, screening and registration of newcomers, after which those seeking asylum should be swiftly channelled to the Greek mainland and other member states.

- Prioritize alternative types of accommodation where the rights of applicants can be respected. Priority should be given to housing in the community, so as to facilitate interaction between locals and asylum seekers/refugees in a manner that respects all parties' dignity.

- Urgently address the situation of homelessness among recognized refugees, including by extending the period of stay in reception facilities to six months after recognition of refugee status. The government should use this time to ensure refugees have all the necessary preparation to integrate into Greek civic life, as part of a broader social policy that supports the most vulnerable people, irrespective of citizenship. Evictions must be avoided at all costs amid the ongoing COVID-19 pandemic.

- Work towards establishing and implementing a comprehensive integration policy. Work on integration should start from the reception stage, with the participation of Greek authorities, community representatives and relevant agencies and organizations.

- Ensure easy access to information about family reunification procedures from the first moment of arrival, including about the necessary documentation, expected timelines and arrivals' right to family life. Access to interpreters, legal assistance and support should be provided throughout the process.

We urge member states to:

- Assume their legal responsibilities under the Dublin III Regulation, including prioritizing the right to family life, and removing any unnecessary technical barriers that undermine asylum seekers' rights. Any bureaucratic requirements that put a burden on asylum seekers should be cross-checked against the likelihood that asylum seekers would be able to comply, given the circumstances in Greece and the availability of funds.

- Inform all relevant civil servants about the situation in Greek reception centres, and consider this information in assessments whenever relevant, for example when considering refusing 'take charge' requests or when determining the best interests of children. The best interests of children must always be the primary consideration in all procedures concerning minors.

- Speed up the processing of 'take charge' applications and transfers, in order to avoid long periods in which asylum seekers wait in limbo and suffer deterioration in their mental and physical health.

- Commit to the relocation of asylum seekers out of Greece, and implement all the commitments that have already been made.

- Ensure family members in their territory are informed of their rights and responsibilities, and are assisted throughout the family reunification procedure. 
We urge the European Commission to:

- Support the Greek government in improving its reception system, and fund only safe and dignified accommodation for all, including protection measures against COVID-19.

- Work with the Greek authorities to evacuate all camps on the Aegean islands and end all policies that restrict the movement of people in inadequate reception centres.

- Continue to support ad hoc relocation mechanisms from Greece to other member states until more durable solutions are found.

In negotiations on the new Pact, we urge all member states and the European institutions to:

- Avoid recreating the current Greek reception model, which fails to protect asylum seekers' rights. In particular, avoid conducting asylum procedures at external borders, where the necessary assistance cannot be guaranteed.

- Protect the right to family life by prioritizing family reunification over other considerations. Family members - defined as broadly as possible - should be able to reunite and support each other.

- Ensure deadlines for family reunification procedures remain effective. Cutting deadlines too short will obstruct the right to family life, as is already evident.

- Promote mandatory responsibility-sharing through relocation as the primary solidarity instrument, particularly in times of increased arrivals. A mandatory relocation mechanism should increase predictability and ensure the accountability of member states in complying with their responsibilities. 


\section{ANNEX I}

Comparison between EU countries, based on key factors and number of asylum applications (see chapter 3 )

\begin{tabular}{|c|c|c|c|c|c|}
\hline Country & GDP (in $€ m$ ) & $\begin{array}{l}\text { Country area } \\
\left(\text { in } \mathbf{k m}^{2}\right)\end{array}$ & $\begin{array}{l}\text { Population (in } \\
10,000 \text { ) }\end{array}$ & $\begin{array}{l}\text { Asylum and } \\
\text { first-time } \\
\text { asylum } \\
\text { applications }\end{array}$ & $\begin{array}{l}\text { Pending } \\
\text { asylum } \\
\text { applications }\end{array}$ \\
\hline Belgium & $476,203.3$ & 30,280 & $1,145.55$ & 23,105 & 29,065 \\
\hline Czech Republic & $223,950.3$ & 77,220 & $1,064.98$ & 1,570 & 775 \\
\hline Finland & 240,561 & 303,910 & 551.79 & 2,445 & 8,315 \\
\hline France & $2,425,708$ & 547,557 & $6,701.28$ & 138,290 & 160,785 \\
\hline Germany & $3,449,050$ & 349,360 & $8,301.92$ & 142,450 & 326,770 \\
\hline Greece & $183,413.5$ & 128,900 & $1,072.45$ & 74,910 & 105,450 \\
\hline Hungary & $146,061.8$ & 90,530 & 977.27 & 465 & 235 \\
\hline Italy & $1,789,747$ & 294,140 & $6,035.95$ & 35,005 & 47,020 \\
\hline Portugal & 213,301 & $91,605.6$ & $1,027.66$ & 1,735 & 180 \\
\hline Romania & $222,997.6$ & 230,080 & $1,941.44$ & 2,455 & 930 \\
\hline Spain & $1,244,772$ & 499,564 & $4,693.70$ & 115,175 & 133,020 \\
\hline Sweden & $474,468.2$ & 407,310 & $1,023.01$ & 23,125 & 27,530 \\
\hline $\begin{array}{l}\text { Source (year) } \\
\text { All last } \\
\text { accessed } 7 \\
\text { February } 2021 .\end{array}$ & $\begin{array}{l}\text { https://bit.ly/2 } \\
\text { N1FQYD (up } \\
\text { to } 2019 \text { for all } \\
\text { states } \\
\text { concerned) }\end{array}$ & $\frac{\text { https://bit.ly/3c }}{\underline{\text { InQun (2018) }}}$ & $\begin{array}{l}\text { https://bit.ly/3 } \\
\text { pZXqL5 (up to } \\
\text { 1 January } \\
\text { 2019) }\end{array}$ & $\begin{array}{l}\text { https://bit.ly/2 } \\
\text { YUNeaU (2019 } \\
\text { for conformity/ } \\
\text { alternative: to } \\
\text { add up } \\
\text { available } \\
\text { numbers up to } \\
\text { November } \\
2020)\end{array}$ & $\begin{array}{l}\text { https://bit.ly/3t } \\
\text { DIDJm } \\
\text { (December } \\
\text { 2019/same as } \\
\text { previous) }\end{array}$ \\
\hline
\end{tabular}




\section{NOTES}

1 European Council. (2016). EU-Turkey statement, 18 March 2016. https://bit.ly/3hVm9NB

2 European Commission. (2015, May 13). Communication from the Commission to the European Parliament, the Council, the European Economic and Social Committee and the Committee of the Regions: a European Agenda on Migration. https://bit.ly/2JU2b9i, p.6

3 European Commission. (2015, September 11). The hotspot approach to managing exceptional migratory flows. https://bit.ly/35gMC35.

4 For more, see European Court of Auditors. (2019). Special Report No 24/2019: Asylum, relocation and return of migrants: Time to step up action to address disparities between objectives and results. https://bit.ly/35rx3FC, pp.20-26.

5 For instance: A. Konstantinou et al. (2020). Report on Greece, update 2019. https://bit.ly/3s70wfY. Greek Council for Refugees (GCR), pp.61-62, 89, 98-99, 120121. Asylum Information Database (AIDA).

Human Rights Council. (2017, April 24). Report of the Special rapporteur on the human rights of migrants on his mission to Greece, A/HRC/35/25/Add.2. https://bit.ly/2LB5VgE, paragraph 85.

6 For more information on this, also see: N-R. Kafkoutsou and S-V. Oikonomou. (2020). Diminished, Derogated, Denied: How the right to asylum in Greece is undermined by the lack of EU responsibility sharing. Oxfam and GCR. DOI: 10.21201/2020.6256. https://www.oxfam.org/en/research/diminished-derogated-denied-how-right-asylumgreece-undermined-lack-eu-responsibility

7 Eurostat. (n.d.-a). First instance decisions on applications by citizenship, age and sexannual aggregated data (rounded). Online data code: MIGR_ASYDCFSTA, updated 28 January, 2021, available at:

https://ec.europa.eu/eurostat/databrowser/view/migr asydcfsta/default/table?lang=en and quarterly data (rounded) available at:

https://ec.europa.eu/eurostat/databrowser/view/migr asydcfstg/default/table?lang=en

8 Eurostat, (n.d.-a) Final decisions in appeal or review on applications by citizenship, age and sex - annual data (rounded). Online data code: MIGR_ASYDCFINA, updated 4 February 2021; and Ministry of Migration and Asylum. (2020). Yearly Report: 2020. https://bit.ly/2Lq6dad, p.15.

Note: There are some variations in the data presented on Eurostat which the authors were not able to rectify. There has also been a significant annual decrease in the rate of recognitions on appeal, from $46.6 \%$ in 2016 to $5.15 \%$ in 2020 . One possible explanation for this decrease is the impact of the amendments to the Greek International Protection Act. For more on this, see, A. Konstantinou et al. (2020). Report on Greece, update 2019, pp. 64-65.

9 Through an amendment to asylum legislation (i.e. IPA) in March 2020, the time that refugees are allowed to remain in accommodation they had been provided during the asylum procedure as per Greece's legal obligations has, with scarce exceptions, been severely reduced from six months to one month. See art. $111 \mathrm{~L}$. 4674/2020 amending article 114 IPA: https://www.e-nomothesia.gr/autodioikese-demoi/nomos-4674-2020phek-53a-11-3-2020.html (in Greek).

10 As repeated throughout the text of the explanatory memorandum accompanying the legislative amendment of article 114 L. $4636 / 2019$ (also known as IPA) with article $111 \mathrm{~L}$. 4674/2020 to reduce the time beneficiaries of international protection are allowed to stay in reception-based accommodation from six months to one month Explanatory Memorandum nr. 218/41 5.3.2020 regulating issues under the competence of the Ministry of Migration and Asylum. Available in Greek at: https://bit.ly/2MAfdtx, pp.2, 20-22.

11 European Commission. (2020, September 23). Migration and Asylum Package: New Pact on Migration and Asylum documents adopted on 23 September 2020. https://ec.europa.eu/info/publications/migration-and-asylum-package-new-pactmigration-and-asylum-documents-adopted-23-september-2020 en 
12 Regulation (EU) No 604/2013: https://bit.ly/3aC6tvl

13 Recital n. 14 of the Dublin Regulation: https://eur-lex.europa.eu/legalcontent/EN/TXT/HTML/?uri=CELEX:32013R0604\&from=en\#d1e679-31-1

14 European Commission. (n.d.). The Dublin System. https://ec.europa.eu/homeaffairs/sites/homeaffairs/files/what-we-do/policies/european-agendamigration/background-information/docs/20160406/factsheet the dublin system en.pdf

15 UNHCR. Operational Poral: Refugee Situations. Mediterranean Situation: Greece. https://data2.unhcr.org/en/situations/mediterranean/location/5179

16 Hellenic Republic Ministry of Citizen Protection. General Secretariat for Information and Communication. National Situational Picture Regarding the Islands at Eastern Aegean Sea (31/12/2019). 1 January 2020. https://bit.ly/36KzvYA.

17 European Parliamentary Research Service. (2020). Dublin Regulation on international protection applications, European Implementation Assessment. https://www.europarl.europa.eu/thinktank/en/document.html?reference=EPRS STU(20 20)642813

18 M.S.S. v. Belgium and Greece. 'The Court found that there was a violation of Article 3 ECHR by the Greece Government because of the applicant's conditions of detention, violation of Article $3 \mathrm{ECHR}$ by Greece concerning the applicant's living conditions in Greece, violation of Article 13 taken in conjunction with Article 3 ECHR against Greece because of the deficiencies in the asylum procedure followed in the applicant's case and the risk of his expulsion to Afghanistan without any serious examination of the merits of his asylum application and without any access to an effective remedy.' See ECtHR - M.S.S. v Belgium and Greece [GC], Application No. 30696/09. European Database of Asylum Law. https://www.asylumlawdatabase.eu/en/content/ecthr-mss-vbelgium-and-greece-gc-application-no-3069609

19 M.S.S. vs Belgium and Greece, para 223.

20 Greek National Commission for Human Rights (GNCHR). STATEMENT in response to the recommendation of the European Commission to reactivate the refugee return mechanism under the Dublin system. 19 December 2016. https://bit.ly/39WDAuW. A. Konstantinou et al. (2020). Country Report Greece: 2019 Update, pp.79-80.

21 Ministry of Migration and Asylum. Dublin National Unit Statistics (7.6.2013 29.02.2020)

22 See Council Decision (EU) 2015/1523, 14 September 2015: https://bit.ly/3ipcmj0 and Council Decision (EU) 2015/1601, 22 September 2015: https://bit.ly/35SEEgR.

23 For instance, see European Commission. (2016). Annex to the Communication from the Commission to the European Parliament, the European Council and the Council: First report on relocation and resettlement. https://bit.ly/3qquf06

24 Article 13(3) of both Council Decision (EU) 2015/1523, 14 September 2015: https://bit.ly/3ipcmi0; and Council Decision (EU) 2015/1601, 22 September 2015: https://bit.ly/35SEEgR.

25 EuropeanMigrationLaw.eu. Relocation of asylum seekers from Italy and Greece, as of 31 May 2018: https://bit.ly/35TBpG5.

26 For an evaluation of the scheme's implementation, see:

European Court of Auditors. (2019). Asylum, relocation and return of migrants: Time to step up action to address disparities between objectives and results. https://bit.ly/39F6Apy, pp.20-27.

European Court of Auditors. (2019). Special Report No 24/2019: Asylum, relocation and return of migrants, p.23.

27 Ibid. p.23 
28 Sixteen states are part of the initiative: Belgium, Bulgaria, France, Croatia, Finland, Germany, Iceland, Ireland, Italy, Netherlands, Norway, Portugal, Luxembourg,

Lithuania, Slovenia and Switzerland. European Commission. (2020, December 17). 2000 vulnerable asylum seekers and recognized refugees relocated this year from Greece. https://ec.europa.eu/home-affairs/news/2000-vulnerable-asylum-seekersand-recognised-refugees-relocated-yeargreece en?fbclid=IwAR394kuYg CNcahLscvo0DLgekV-tS-yBwgf7LhugV4Jta78TXD3pKJuK0

29 European Commission. Ylva Johansson letter in response to FEANTSA and the Greek Housing Network call for dignified accommodation for former residents of the Moria Centre (Ares (2020)7447303, 7 December 2020).

30 Out of the 2,050 persons relocated, 553 were unaccompanied children; 1,186 were still undergoing the asylum procedure (families); and 311 had already received international protection status (families). International Organization for Migration (IOM). (2020). Voluntary scheme for the relocation from Greece to other European countries. https://greece.iom.int/sites/default/files/201217 $0 . p d f$

31 Article $2 \mathrm{~g}$ of the Dublin Regulation: https://eur-lex.europa.eu/legalcontent/EN/TXT/HTML/?uri=CELEX:32013R0604\&from=en\#d1e679-31-1

32 For more, see:

S. Cravesana and M. Hennessy. (2017). Left in Limbo: UNHCR Study on the Implementation of the Dublin III Regulation. UNHCR.

https://www.refworld.org/docid/59d5dcb64.html, pp.102-1044.

Danish Refugee Council. (DRC). When the Dublin Systems Keeps Families Apart. https://www.drc.ngo/media/bmlotrlk/drc-policy-brief-when-the-dublin-system-keepsfamilies-apart-may-2018-final.pdf, pp.5-11.

33 European Parliamentary Research Service. (2020). Dublin Regulation on international protection applications, European Implementation Assessment. https://www.europarl.europa.eu/thinktank/en/document.html?reference=EPRS STU(20 20)642813, pp.35-37.

34 A. Konstantinou et al. (2020). Report on Greece, update 2019. https://bit.ly/3s70wfY. Greek Council for Refugees (GCR), pp.78-79.

35 lbid, p. 72.

36 Article 21(1): 'Where a Member State with which an application for international protection has been lodged considers that another Member State is responsible for examining the application, it may, as quickly as possible and in any event within three months of the date on which the application was lodged within the meaning of Article 20(2), request that other Member State to take charge of the applicant.' Dublin Regulation: https://eur-lex.europa.eu/legalcontent/EN/TXT/HTML/?uri=CELEX:32013R0604\&from=EN\#d1e1082-31-1

37 Article 22(1): 'The requested Member State shall make the necessary checks, and shall give a decision on the request to take charge of an applicant within two months of receipt of the request.' 'lbid.

38 Article 29(2): 'Where the transfer does not take place within the six months' time limit, the Member State responsible shall be relieved of its obligations to take charge or to take back the person concerned and responsibility shall then be transferred to the requesting Member State. This time limit may be extended up to a maximum of one year if the transfer could not be carried out due to imprisonment of the person concerned or up to a maximum of eighteen months if the person concerned absconds.' Ibid. 
39 Statistics for 2020 are not yet available. During 2019, EU member states (excluding Czech Republic and Portugal, for which data are not available) reported that on average $76 \%$ of incoming transfers in 2019 were completed within six months of the request being accepted, with $16 \%$ completed within a further six months, and the remaining $8 \%$ within the final possible six-month period (13-18 months total). Eurostat. (2020). Dublin statistics on countries responsible for asylum application. https://ec.europa.eu/eurostat/statisticsexplained/index.php/Dublin statistics on countries responsible for asylum applicati on\#Implemented transfers within the Dublin procedure, figure 15.

40 Applications based on discretionary/humanitarian clauses are based on Article 17 of the Dublin III Regulation, which permits member states to submit 'take charge' requests to bring together any family relations on humanitarian grounds. According to GCR's experience, requests under the humanitarian clause mainly concern dependent and vulnerable persons who fall outside the family criteria set out in Articles 8- 11 and/or cases where the three-month deadline for a request has expired for various reasons. A. Konstantinou et al. (2020). Report on Greece, update 2019, p.74.

41 'In 2019, Greece addressed 5,459 take charge requests to other member states under the Dublin Regulation. Out of them, 2,936 requests were rejected by receiving member states, 2,416 requests were expressly accepted and 107 were implicitly accepted. Thus, for the first time since the start of Dublin III, Greece received more rejections than acceptances of its outgoing requests.' Ibid, p.71.

42 The requests were sent to Germany, the UK, Switzerland, Sweden, the Netherlands, Italy, Belgium, Finland, France, Austria, followed by other countries, as per information GCR received from the Greek Dublin Unit on 8 February 2021. The breakdown of the number of women and men was not available to the Dublin Unit.

43 As per information GCR received from the Greek Dublin Unit on 8 February 2021, 80\% of the requests Greece received were based on Article 18.1 (b) of the Regulation, followed by Article 13.1 of the Regulation. The main nationalities of applicants are Syria, Afghanistan, Iraq, Iran, and of Palestinian origin.

44 Due to the nature of the Dublin procedure, these numbers also concern take charge requests sent by Greece during 2019 for which the reply came in 2020.

45 Germany, the UK, Switzerland, Sweden, the Netherlands, Italy, Belgium, Finland, France, Austria, followed by other countries, as per information GCR received from the Greek Dublin Unit on 8 February 2021.

46 Written consent from the relative is required, as well as documents proving their legal status in the receiving country and documentation proving the family link, such as a marriage certificate or a passport.

47 Where documentation proving family links is missing, a DNA test is requested to prove family ties. Member states such as Germany and Spain usually ask for a DNA test in such cases. In certain member states, the use of DNA tests to establish a family link is becoming more of a standard practice than a last resort. A. Konstantinou et al. (2020). Report on Greece, update 2019, p.73.

48 Greek Ministry of Justice, Transparency and Human Rights. List of 13 available public forensic services in 13 large cities of Greece, according to the Ministry of Justice, Transparency and Human Rights (in Greek). Available at: tinyurl.com/oy3j36b9.

49 As per information GCR received from the Greek Dublin Unit on 8 February 2021.

50 A. Konstantinou et al. (2020). Report on Greece, update 2019, p.73.

51 Member states that request a translation into English are Germany, the Netherlands, Spain and Italy, a requirement that, among other issues, significantly delays the procedure. 
52 Article 13-31 of Law 4554/2018. Although, the new regulatory framework for guardianship of unaccompanied children was established in Greek law 4554/2018 and was supposed to take effect on 1 March 2020, it has not yet been implemented. See the open letter from civil society organizations regarding the protection of thousands of unaccompanied children in Greece, published on 25 February 2020: http://www.arsis.gr/anoichti-epistoli-organoseon-tis-koinwnias-politwn-anaforikaprostasia-xiliadwn-asynodeytwn-paidiwn-ellada/

53 For example, if the relative residing in the receiving country did not provide proof of a rental contract and/or regular employment. The UK is known to be the most likely to reject cases on this basis, although in one such case handled by GCR, Germany also rejected reunification for a minor because their uncle did not prove that the child would have a separate room from their cousins. In that case, and many others like it, the minor was thus separated from their family and forced to remain in a camp in Greece, presumably a far worse option than sharing a room with family in a private apartment.

54 Mostly by Scandinavian countries and Austria, as per information GCR received from the Greek Dublin Unit on 8 February 2021.

55 In one such case handled by Fenix - Humanitarian Legal Aid, Austria accepted an entire family residing in Greece with the exception of the 17-year-old daughter. Although Greece had already conducted an age assessment proving the daughter was a minor, Austria refused to accept the result.

56 MdM. (2016). Assessment of minority of unaccompanied foreign minors: Thoughts and concerns. Available in Greek at: https://bit.ly/36qqvrC.

57 As is their obligation under article 4 of the Dublin Regulation.

58 A.M.A. Scherrer. (2020). Dublin Regulation on international protection applications. European Parliament Think Tank. https://www.europarl.europa.eu/thinktank/en/document.html?reference=EPRS STU(2 $\underline{020) 642813}$, p.35

As has been observed in practice by GCR and Fenix - Humanitarian Legal Aid.

60 CJEU. Case C-670/16 Tsegezab Mengesteab v Bundesrepublik Deutschland. Judgment of 26 July 2017, EDAL, available at: https://bit.ly/2XvMKq2)

61 Several countries - Germany, France, Italy, Belgium, Greece and Croatia - that distinguish between 'registration' and 'lodging' of an asylum application in their systems have aligned their practice with the Mengesteab ruling and have started counting the three-month time limit from the moment the asylum seeker's intention to seek international protection is registered.

European Council on Refugees and Exiles. (ECRE). (2019). The implementation of the Dublin III Regulation in 2018.

http://www.asylumineurope.org/sites/default/files/aida 2018update dublin.pdf, p.12

European Parliamentary Research Service. (2020). Dublin Regulation on international protection applications: European Implementation Assessment. https://www.europarl.europa.eu/RegData/etudes/STUD/2020/642813/EPRS STU(202 0)642813 EN.pdf, p.68.

62 The calculation of time limits for sending 'take charge' requests has changed in many countries following the Court of Justice of the EU's 2017 ruling in Mengesteab (see, CJEU, Case C-670/16 Tsegezab Mengesteab v Bundesrepublik Deutschland, link in endnote 60 ) which allows the time period to start as soon as information on the existence of a document certifying a request for protection has reached the competent authorities. This finding has been interpreted as meaning that the procedure may start immediately after initial registration steps, even before the official lodging of an application.

63 As identified by 19 civil society organizations in Greece in a letter sent on 6 July 2020 to the Special Secretariat for the Protection of Unaccompanied Minors in Greece (not available online). 
64 As per information GCR received from the Dublin Unit on 8 February 2021, no transfers took place from Greece to other member states from March to July 2020, with the exception of two group transfers (73 people in May and 29 people in June). During the second half of 2020, due to COVID-19 measures, flights to other member states were significantly limited, as was the number of people arriving in member states, due to the restrictions put in place by the airlines.

It must be noted that on April 2020 the Commission encouraged all member states to resume transfers as soon as practicably possible in view of the evolving circumstances. European Commission. (2020). Guidance on the implementation of relevant EU provisions in the area of asylum and return procedures and on resettlement (2020/C 126/02). https://eur-lex.europa.eu/legalcontent/EN/TXT/?uri=CELEX:52020XC0417(07)

65 Such as extended backlogs, limitations on the number of people arriving by plane in the territory of member states, limited flights, flights being cancelled (as is the case with flights to Germany, Austria and Italy) and restrictions from the airlines, according to information from the Dublin Unit.)

66 In the absence of legal alternatives for people seeking protection, the (Western) Balkans Route was among the main ways in which refugees and migrants reaching Greece (or Bulgaria) attempted to move onwards into the EU, by initially crossing the land borders between Greece and Northern Macedonia and moving onwards towards Hungary, Croatia and Western Europe. In 2015, at the height of the crisis, more than 760,000 people, primarily from Syria, Iraq and Afghanistan, used this route. By March 2016, border closures and stricter controls marked the route's closure. Increased violence and pushbacks against people that have since attempted to cross the route, at least, through Croatia, have been reported. See for example: Moschopoulos, M. 2019. The "Balkan Route": Three Years after Its Closure. https://bit.ly/2YSp1Sz, pp. 34; and FRONTEX. Migratory Routes: Western Balkan Route. https://bit.ly/2N31ewC.

67 Based on the latest available data at the time of writing, between 2016 and the end of $2020,354,334$ refugees and migrants were estimated to have arrived in Greece. See UNHCR data: https://data2.unhcr.org/en/situations/mediterranean/location/5179

68 See Eurostat data on asylum and first-time asylum applicants by citizenship, age and sex. Annual data:

https://ec.europa.eu/eurostat/databrowser/view/migr asyappctza/default/table?lang=e n. Monthly data: https://ec.europa.eu/eurostat/databrowser/view/MIGR ASYAPPCTZM custom 353 942/default/table?lang=en.

69 For some of the latest publications, see ARSIS, GCR and others. (1 February 2021). Joint Statement on push backs practices in Greece. https://bit.ly/36Lez3N; RSA. (2020a). Push backs and violations of human rights at sea: a timeline. https://bit.ly/3sWarrd

Border Violence Monitoring Network. (2020). The Black Book of Pushbacks. Available in two volumes. https://bit.ly/2Y8zLvX.

70 Eurostat annual and monthly data on first-time asylum applicants by citizenship, age and sex. See endnote 68 .

71 For instance, see A. Konstantinou et al. (2020). Country Report Greece: 2019 update, pp. 49, 55.

$72 \mathrm{lbid}$. The extremely truncated fast-track border procedure on the islands was introduced in Greece for the first time in April 2016, just weeks after the implementation of the EU-Turkey Statement. It was 'visibly connected' with the Statement's implementation.

73 Ibid, p.79. 
74 Eurostat. (n.d.-b). Persons subject of asylum applications pending at the end of the month by citizenship, age and sex - monthly data (rounded). Online data code MIGR_ASYPENCTZM. Data last updated 28 January 2021. https://bit.ly/3c9Rc7i. Note: The data published by the Greek Ministry of Migration and Asylum for the same month was 79,353 , and 76,335 for December 2020. When including pending appeals the number of cases, according to the Ministry of Migration and Asylum, stood at 83,204 for November and 79,888 for December. See Ministry of Migration and Asylum. (19 January 2020). Annual Brief for 2020. Available at: https://bit.ly/38Ud0lr, p.11.

75 See: European Asylum Support Office (EASO). (2020). COVID-19 emergency measures in asylum and reception systems. Issue no. 2. https://bit.ly/2LIrE6k, p.9.

The relevant decisions suspending the operations of the asylum service for the public can be found at: https://www.e-nomothesia.gr/kat-ygeia/astheneies/koine-upourgikeapophase-12687-2020.html and https://www.e-nomothesia.gr/katygeia/astheneies/koine-upourgike-apophase-3332-2020.html.

76 See: GCR and others. (2020, March 6). "Protect our laws and humanity!": Open Letter by 256 Organizations. https://bit.ly/2XuhzMW

GCR and others. (2020, March 25). Protect the most vulnerable to ensure protection for everyone! Open letter of 121 organizations. https://bit.ly/3qeX7vY.

77 Data published by the Ministry of Migration and Asylum shows that close to $44 \%$ of the total number of first-instance asylum decisions were issued between March and May, with the largest number having been issued in April $(15,853)$. Ministry of Migration and Asylum. (2020). Monthly Brief. September 2020. https://bit.ly/39qXIt6

Note: Occasionally there seems to be a quite significant divergence between the data provided by the ministry in its monthly briefs and that issued by Eurostat. Determining the cause of this divergence could serve to provide a clearer picture.

78 A total of 65,040 decisions were issued at first instance in 2018 and 2019; in 2020 up to September, the total number of first-instance decisions stood at 43,020 . In September 2020, 75,675 decisions were still pending their first decision. See Eurostat's First instance decisions on applications by citizenship, age and sex:

- $\quad$ annual aggregated data (rounded) https://bit.ly/3oGcvRt

- $\quad$ quarterly data (rounded) https://bit.ly/3qg0kLo

- $\quad$ monthly data (rounded) https://bit.ly/3qcnuma.

79 Eurostat. (2020, July 10). EU population in 2020: almost 448 million. https://bit.ly/3qirxgC, p.1.

Eurostat. (2020, May 7). Which EU countries had the highest GDP in 2019? https://bit.ly/2LHN4jU.

80 See: Council of Europe Commissioner for Human Rights. (2019, October 31). Greece must urgently transfer asylum seekers from the Aegean islands and improve living conditions in reception facilities. https://bit.ly/3bU8Vii

J. Le Blond. (2019, November 28). UNHCR chief urges action over conditions for asylum-seekers on Greek island. UNHCR. https://bit.ly/3nZ6YUM

A. Konstantinou et al. (2020). Country Report Greece: 2019 update pp.154-161.

RSA. (2019, May 22). Reception crisis in Northern Greece: Three years of emergency solutions. https://bit.ly/3nYz6aH

81 General Secretariat of Information and Communication. (2020, January 1). National Situational Picture Regarding the Islands at Eastern Aegean Sea (31/12/2019).

82 See UNHCR data: https://data2.unhcr.org/en/situations/mediterranean/location/5179 and https://data2.unhcr.org/en/situations/mediterranean/location/5179 
83 Ministry of Migration and Asylum. (2020, January 19). Annual brief for 2020. Available in Greek at: https://bit.ly/38Ud0lr, pp.2-3.

Note: in January 2021, the Ministry of Migration proceeded with the welcome publication of expanded data on asylum and migration, covering the whole period of 2020. Unfortunately, some data diverges from that provided by Eurostat, seemingly due to different methodological approaches (e.g. on the type of decisions counted for the purposes of statistically quantifying percentages of status recognition). In order to maintain a uniform approach throughout this paper, particularly since this data was published too close to the paper being finalized, we have not been able to include it throughout the whole report.

84 General Secretariat of Information and Communication. (2020, January 1). National Situational Picture Regarding the Islands at Eastern Aegean Sea (31/12/2020).

85 UNHCR. 5 January 2021. Aegean Islands Weekly Snapshot (28 December 2020 - 03 January 2021). https://bit.ly/3tA3Jr5. At the time, UNHCR estimated the total number of refugees and asylum seekers on the islands to be 19,100 .

86 M. Kiskila. (2020, December 19). In the hell of Kara Tepe: 'they can't make it throughout winter in the mud'. Tvxs. Available in Greek at: https://bit.ly/2LyniyG

G. Pagoudis. (2020, December 14). The flood in Kara Tepe exposes the Minister of Migration. Efsyn. Available in Greek at: https://bit.ly/3bGjNRx.

87 GCR and others. (26 January 2021). Stop playing with people's lives: urgent need to protect the health of residents and employees in the Lesbos RIC.

https://bit.ly/3jz0vQ8. For the Ministry's announcement, see: Ministry of Migration and Asylum. (2021, January 23). Reply to publications: Below international limits the levels of lead in the accommodation spaces of the temporary RIC in Mavrovouni, Lesvos. Available in Greek at: https://bit.ly/2KOQx00.

88 Newsbeast. (2020, December 22). Rats, scorpions and snakes bit children and adults - not in Lesbos - but in Samos. Available in Greek at: https://bit.ly/2XJI7e5

89 International Rescue Committee. (2020). The Cruelty of Containment: The Mental Health Toll of the EU's 'Hotspot' Approach on the Greek Islands. https://bit.ly/2XWKyJA, pp.14-15.

90 See:

IOM. (2020). Supporting the Greek Authorities in Managing the National Reception System for Asylum Seekers and Vulnerable Migrants (SMS). https://bit.ly/2Nfagst.

(2021, January 21). Schools: Serious complaints by professionals in education refugee children remain out of school. Available in Greek at: https://bit.ly/2M2VV03.

91 Papataxiarchis E. 2020. The new geography of the refugee issue: Violence and the

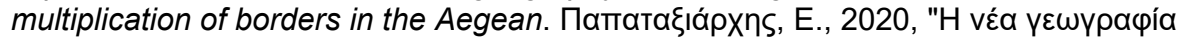

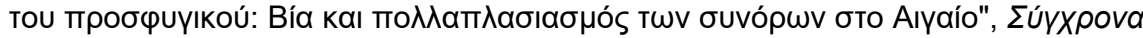

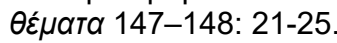

92 See: RSA. (31 October 2018), Increase in xenophobic and racist incidents on the islands in the last semester. https://bit.ly/3p04ztJ.

93 For 2018 and 2019 data, see: Eurostat. (n.d.-a). First instance decisions on applications by citizenship, age and sex - annual aggregated data (rounded). https://bit.ly/2M7y8f6. For 2020 data, see: Ministry of Migration and Asylum. (2020, January 19). Annual brief for 2020. Available in Greek at: https://bit.ly/38UdOlr.

94 In 2019, less than one in four children asylum seekers benefited from access to school on the Greek islands. UNHCR. (2019). Stepping up: Refugee Education in Crisis. https://bit.ly/3tFxkPK, pp. 13, 20-21. During 2020, the COVID-19 pandemic has also impacted on children refugees'/asylum seekers' ability to attend school-based education on the mainland. 
95 As of December 2020, out of the 28,356 people residing in Greece's 32 mainland sites, less than $33 \%$ had obtained a fiscal registration number (AFM), which is required for them to be able to work. As per information received from UNHCR in February 2020, an estimated 11,000 are recognized refugees, though it is not possible to estimate the extent to which they are specifically affected due to the lack of broken down data. Of the 6,409 recognized refugees residing under the ESTIA (apartment-based) accommodation scheme, as of 28 December 2020, three out of ten still lacked a social security number (AMKA), 57\% lacked an AFM, only one in five had managed to secure an unemployment card, and merely $6 \%$ had been able to open a bank account (to be able to receive payments, if they manage to get a job). The relevant statistics for asylum seekers living under the ESTIA scheme were even lower. International Organization for Migration (IOM). (December 2020). Supporting the Greek Authorities in Managing the National Reception System for Asylum Seekers and Vulnerable Migrants (SMS). https://bit.ly/2Nfqgst; UNHCR. (28 December 2020). Population breakdown in ESTIA II Accommodation Scheme. https://bit.ly/3oZY4Hk.

96 Out of the 26,665 beneficiaries of international protection that have enrolled in Helios since its operationalization in July 2019 , only $41 \%(11,009)$ have accessed the programme's specific component. IOM. (February 2021). Helios factsheet (16/07/2019 - 05/02/2021). https://bit.ly/3jtPteM

97 Eurostat. (2020, October 22). Second quarter of 2020 compared with first quarter of 2020: Government debt up to $95.1 \%$ of GDP in euro area. https://ec.europa.eu/eurostat/documents/2995521/11442886/2-22102020-BPEN.pdf/a21ffbf8-09c9-b520-8fa9-6e804146bf0f

98 Eurostat. (21 January 2021). Third quarter of 2020: Government debt up to $97.3 \%$ of GDP in euro area. https://bit.ly/2MLqRCh, p.1; and Eurostat. (8 January 2021). November 2020: Euro area unemployment at 8.3\%. https://bit.ly/3cOeekx, p.4.

99 According to an amendment to Greek asylum legislation on 13 March 2020 (art. $111 \mathrm{~L}$. $4674 / 2020$ amending article 114 IPA), beneficiaries of international protection are expected to leave their accommodation within 30 days of notification of their positive asylum decision. In the case of unaccompanied minors, the countdown to this deadline starts from the time they turn 18. Amendment available at: https://www.enomothesia.gr/autodioikese-demoi/nomos-4674-2020-phek-53a-11-3-2020.html

100 Article 6(2) of Joint Ministerial Decision of the Ministers of Development and Investment and of Migration and Asylum on "Conditions for the provision of material reception conditions under the "ESTIA II" programme for the accommodation of applicants of international protection. Gazette 1199/B/7-4-2020.

https://bit.ly/2MB0qzo; and article 21 of Ministerial Decision of the Minister of Migration and Asylum on the "General Rules of Operation of Temporary Reception Structures and Temporary Accommodation Structures for third country nationals or stateless persons that operate under the auspices of the Reception and Identification Service. Gov. Gazette 5272/B/30-11-2020. https://bit.ly/3jrHrDp.

101 Proto Thema. (7 March 2020).Refugees: No more allowances and benefits to those that have [been granted] asylum says Mitarakis. https://bit.ly/2MN6On9.

102 Proto Thema. (5 March 2020). Migrants - Mitarakis at Thema 104,6: 'I don't exclude anything' on closed centers on islets. https://bit.ly/3rCVKrz; Proto Thema. (5 March 2020). Migration Issue: This is the amendment for refugees to leave the islands. https://bit.ly/3aQe9KO; Capital.gr. (22 May 2020). N. Mitarakis: 15\% decrease in the number of refugees and migrants residing on the islands compared to the start of 2020. https://bit.ly/3jvioiH.

103 Also see RSA. (2020b). Recognised but unprotected: The situation of refugees in Victoria Square. https://bit.ly/2YcGHbf. Concerns over the premature end to necessary support for refugees, particularly in the absence of an effective safety net, was inter alia also highlighted by UNHCR in June 2020. UNHCR. (2 June 2020). Greece must ensure safety net and integration opportunities for refugees - UNHCR. https://bit.ly/3oZzLtc.

104 GCR et al. (2020, December 22). Refugees in Greece: risk of homelessness and destitution for thousands during winter. Open letter from 74 organizations. https://bit.ly/2M2ndnk. 
105 For example, see:

ECRE. (2020, June 5). Greece: 500 to Escape Greece - Thousands Facing Destitution, Detention and Push-backs. https://bit.ly/3iNKVQi

RSA. (2020, June 4). Lack of effective integration policy exposes refugees in Greece to homelessness and destitution, while returns from European countries continue. https://bit.ly/2YfBLIU.

106 European Commission. (2020). Communication from the Commission to the European Parliament, the Council, the European Economic and Social Committee and the Committee of the Regions on a New Pact on Migration and Asylum. https://bit.ly/3pW2uAq

107 See: F. Maiani. (2020, October 20). A "Fresh Start" or One More Clunker? Dublin and Solidarity in the New Pact. EU Immigration and Asylum Law and Policy blog. https://bit.ly/3ogNavA

108 European Parliament, Committee on Civil Liberties, Justice and Home Affairs. (2017). Report on the proposal for a regulation of the European Parliament and of the Council establishing the criteria and mechanisms for determining the Member State responsible for examining an application for international protection lodged in one of the Member States by a third-country national or a stateless person (recast). https://www.europarl.europa.eu/doceo/document/A-8-2017-0345 EN.html.

109 S. Maas, E. Jurado, M. Capdevila, M. Labayle and L. Hayward. (2015). Evaluation of the Dublin III Regulation: DG Migration and Home Affairs Final report. ICF International for the European Commission. https://bit.ly/3a8HUpQ, p.8.

110 European Commission, Proposal for a Regulation on asylum and migration management and amending Council Directive (EC) 2003/109 (Brussels, 23 September 2020), Article 47.

111 European Commission. (2020). Proposal for a Regulation on asylum and migration management and amending Council Directive (EC) 2003/109 and the proposed regulation (EU) XXXIXXX [Asylum and Migration Fund] COM(2020) 610 final. Article 48. https://eur-lex.europa.eu/legal-content/EN/TXT/?uri=COM:2020:610:FIN.

112 O. Sundberg Diez and F. Trauner. (2021). EU return sponsorships: High stakes, low gains? Mercator Dialogue on Asylum and Migration (MEDAM). https://www.medammigration.eu/publications/policy-papers/eu-return-sponsorships-high-stakes-lowgains-15782/

113 This was also raised in comments sent by Greece, Italy, Malta and Spain to the Commission, in which these four frontline member states highlighted the complexity and vagueness of the solidarity mechanism in contrast to the strictly defined responsibilities of first-entry states. No author. (2020). New Pact on Migration and Asylum: comments by Greece, Italy, Malta and Spain. https://bit.Iy/2LWjQ1k

114 See: A. Radjenovic. (2020). Solidarity in EU asylum policy. European Parliament briefing. https://bit.ly/3phc54t, p.7.

115 For instance, throughout 2019 , the average time between the arrival of a person on the islands and the completion of the medical/psychosocial assessment of vulnerabilities was between two to six months for Lesbos, one to eight months for Chios, two to three months for Samos, three to four months for Leros and four months for Kos, as per the latest information provided by the Ministry of migration and Asylum to GCR on 6 February 2020. A. Konstantinou et al. Country Report Greece: 2019 Update, p.107.

116 RSA and others. (26 January 2021). The Workings of the Screening Regulation. https://bit.ly/2YSMOSt, p.2.

117 Similar positions were expressed by interviewees from the Greek Migration Ministry's Dublin Unit, in a written interview conducted on February 2021.

118 Euronews. (23 September 2020). EU migration chief vows new pact will stop overcrowded refugee camps. https://bit.ly/3cW3dh9. 
(C) Oxfam International and Greek Council for Refugees February 2021

This paper was written by Natalia-Rafaella Kafkoutsou and Spyros-Vlad Oikonomou. It is part of a series of papers written to inform public debate on development and humanitarian policy issues.

For further information on the issues raised in this paper please email advocacy@oxfaminternational.org

This publication is copyright but the text may be used free of charge for the purposes of advocacy, campaigning, education, and research, provided that the source is acknowledged in full. The copyright holder requests that all such use be registered with them for impact assessment purposes. For copying in any other circumstances, or for re-use in other publications, or for translation or adaptation, permission must be secured and a fee may be charged. Email policyandpractice@oxfam.org.uk.

The information in this publication is correct at the time of going to press.

Published by Oxfam GB for Oxfam International and Greek Council for Refugees under ISBN 978-1-78748-732-1 in February 2021. DOI: 10.21201/2021.7321.

Oxfam GB, Oxfam House, John Smith Drive, Cowley, Oxford, OX4 2JY, UK. 